\title{
Scitex: A Company At A Crossroads ${ }^{1}$
}

Tamar Almor, (Email: talmor@colman.ac.il), College of Management, Israel

\begin{abstract}
Scitex is one of the first Israeli high tech firms that succeeded internationally and it was an Israeli pioneer regarding the floatation of the firm on NASDEQ. Scitex made an international name for itself in the 1980's by selling prepress systems to major publishers worldwide. The prepress system developed by Scitex allowed printers to prepare material for print in a digital way, thereby expanding printing options and allowing accurate printing of color pictures. While Scitex was very successful during the late 1980's and the beginning of the 1990's, its financial ratios had declined during the 1990's and stockholders had shown their dissatisfaction.
\end{abstract}

During the 1990's, Israel had become a leading force in the high-tech world; the country had become part of the "New Economy" in which "Exposing Value" was the motto. The Board of Directors demanded that Scitex adapt itself to the rules of the new economy in its plans for the future. Rimon Ben-Shaul, Chairman of the Board, contemplated his response to the request of the Board, which would soon demand an answer.

At the end of this case study, the students are required to make recommendations to the Scitex Board of Directors in late 1999 on how to continue "unveiling the company's value", in light of the reining "New Economy" business models and expectations. Several options are raised in the text - (1) issuing stock for each SBU separately; (2) uniting functions and operations where possible between the SBU's; (3) M\&A with another player in the digital printing industry. The students may choose one of the options, a different option not mentioned in the text, or any combinations of the abovementioned options. Without the benefit of hindsight, this dilemma has no right or wrong answers. The students are asked to justify one or more of these strategic alternatives. Their justification should be based on solid evidence presented in the case or on additional data collected on the Internet for from others resources. They should consider the advantages and disadvantages of their alternatives and conceive a plan that will minimize the apparent risks, while taking full advantage of the alternatives' growth and profit potential, as well as pleasing the company's stockholders, which were to be a key consideration in deciding upon the company's future.

The case study allows for a SBU analysis of the core unit, as well as an analysis of the corporate strategy and portfolio management of the company. It allows students to discuss the different strategic options open to management and recommend one of them. The case study is suitable for MBA students who study business strategy, corporate strategy, or international business. Teaching notes can be requested form the author.

\section{INTRODUCTION}

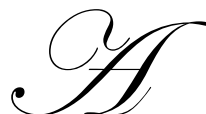

$\mathrm{t}$ the beginning of the $21^{\text {st }}$ century, Israeli high tech was at its peak. Rimon Ben-Shaul, newly appointed Chairman of the Board, was proud to be the head of the company that had started the high tech industry in Israel thirty years ago: Scitex. Thinking about Scitex's future, Ben Shaul wondered how Scitex could further unveil its value and how it should strategically position itself in the future.

\footnotetext{
${ }^{1}$ Copyright Dr. Tamar Almor who prepared this case study with the help of Oren Bier-Katz, Yifat Ziv Koyfman, Hagit Cohen, Keren Saidoff and Udi Lederer. The case was prepared for educational purposes rather than to illustrate either effective or ineffective handling. The case study was funded by the Research Unit of the School of Business Administration, The College of Management.
} 
Scitex had been one of the first Israeli high tech firms to succeed internationally and was an Israeli pioneer regarding the floatation of the firm on NASDAQ. Its Initial Public Offering (IPO) was in 1980, a secondary offering would follow within a couple of years. Scitex made an international name for itself in the 1980s by selling prepress systems to major publishers worldwide. The prepress system developed by Scitex allowed printers to prepare material for print in a digital way, thereby expanding printing options and allowing accurate printing of color pictures. While Scitex was very successful during the late 1980s and the beginning of the 1990s, its financial ratios had declined during the 1990s and stockholders had shown their dissatisfaction.

During the 1990s Israel had become a leading force in the high tech world; the country had become part of the 'New Economy' in which 'Exposing Value' was the motto. At the beginning of the $21^{\text {st }}$ century, The Board of Directors demanded that Scitex adapt itself to the rules of the new economy in its plans for the future. Rimon BenShaul contemplated the answer to the request of the Board, which would soon demand an answer.

\section{BACKGROUND}

Scientific Technology Ltd., later renamed Scitex, was founded in 1968 by Efi Arazi, a daring visionary and specialist in photo and electro-optical imaging. The company's first products were developed for the Israel Defense Forces, and the standards of excellence and innovation established then have guided Scitex throughout the years, setting it apart from the competition.

The Original Vision of Scitex, as described by Efi Arazi in 1967, was as follows:

[The company] will capitalize on the strong scientific and creative resources in Israel to develop an R\&D based manufacturing organization to market industrial, electro-optical centered products in the U.S. and other world markets. $^{2}$

Looking at the non-military market, Scientific Technology opened new commercial frontiers in the early 1970s. Applying its expertise, it developed an image manipulation workstation that automatically programmed looms with double-knit textile patterns. This replaced the complex and tedious stitch-by-stitch drawings and manual card punching. The company changed its name to Sci-Tex (implying textiles), with a logo that hinted at a stylized eye of a double knitting needle, and opened offices in Europe and the USA.

Sci-Tex's workstation generated films for printing textiles. It included sophisticated capabilities such as complex overlapping, trapping, and developing repeat patterns, as well as a scanner for digitizing drawn patterns and a large format electronic laser plotter (ELP) for imaging the films. These technologies laid the foundation for subsequent systems that specialized in mapping, seismography and printed circuit board design. At several trade shows Sci-Tex won awards for Technical Excellence.

Realizing that the market for such textile design systems would soon be saturated, Sci-Tex decided to enter the large, promising, and challenging industry of printing and publishing. In 1975 the company started to develop an electronic prepress workstation, and in 1979 Scitex demonstrated its invention - the world's first computerized, color, prepress system, the 'Response 300', which incorporated a digitizing scanner interface, a page makeup and retouching console, and the ELP image setter.

This introduced the world to the field of color, electronic prepress. The system's debut at the GEC tradeshow in Italy was followed by demonstrations in Print 1980 in the U.S. and IPEX 1980 in Germany, earning a Best of Show award.

In 1980 (and 1983) the company issued OTC stocks, following revenues of \$104 million. In 1981 Sci-Tex directly linked its color electronic prepress system to gravure engravers (Logo), and offered the first color electronic page design and layout system for publishers (Vista) in 1982. Firmly established in the industry, the company changed

\footnotetext{
${ }^{2}$ Memo to Itek management by Efi Arazi, December 1967
} 
its name slightly by dropping the hyphen and combining the two parts into Scitex, while modifying the logo. Once again Scitex anticipated the future, and in the 1980s boldly strode into the digital age - digital imaging began its major impact on prepress.

Scitex invented the first large format, automatic, flatbed image setter/scanner (Raystar) in 1985, a harbinger of high-resolution image setters that were to follow later. In 1986 Scitex introduced the world's first successful, industrial quality, flatbed, CCD (charge-coupled device) scanner, Smart Scanner, and offered the first open architecture program for linking prepress systems and peripherals (Handshake).

The company introduced a 32-bit computer platform dedicated to prepress (Whisper) in 1986, followed by several workstations dedicated to retouching, page assembly, and other tasks. They were compatible with the new office environments that now included PCs and Macs.

From the middle of 1985 till the middle of 1987, Scitex experienced a period of significant losses. The losses were the result of several factors, such as postponements due to technical difficulties in showing the first generation of workstations based on microcomputers, an unsuccessful attempt to diversify its product line, and in addition to government-related changes, due to the high inflation rate in Israel at that time.

Scitex took some major steps to rectify the situation. This included handling technical problems in new products, refocusing the company's efforts in electrical equipment to the color preprint, and putting an emphasis on customer care and service. Scitex also laid-off 500 workers, cut-down salaries, and did not pay out bonuses.

Efi Arazi, Scitex's founder and CEO, decided to give up his entire salary for 1986. The company made some major changes in management; in order to help the company straighten out its financial situation, some key changes in the financial management and operations management were made which enabled the company to cope with the change in the governmental environment as well. As a result of these major steps, Scitex, then still a single SBU, managed to turn its business around and retain its position as a successful Israeli company once more. At the same time, Efi Arazi left Scitex.

The first of the Dolev image setters appeared in 1988, invented by Scitex, as the first internal-drum image setter for high-quality color separations. They subsequently became the industry standard for high-end production. That same year Scitex became the first prepress company to be committed to full Adobe PostScript compatibility. Among its customers at that time Scitex counted Fortune, National Geographic, Time/Warner, The New York Times, USA Today and Us News and World Report.

At the beginning of the 1990s the company was well established in the high-end, pre-press, color segment, where it competed with companies such as Barco, Dai Nippon Screen and Crosfield, although Agfa, Linotype-Hell and Kodak were considered competitors as well in specific products. Financially the company was doing very well and between the years $1990-1992$ it reported net profits of $22 \%$ and over.

In the early 1990s Scitex embarked on an acquisition program designed to expand the company's capabilities and horizons in the industry. The first of these acquisitions was Iris Graphics, Inc., adding high-quality, inkjet printing systems to the company's roster of products, and setting a new industry standard in color proofing. Shortly after that, Scitex acquired Kodak's Dayton operations now known as Scitex Digital Printing (high speed inkjet printers with variable information). Subsequently, Scitex acquired Leaf Systems, Inc., the manufacturer of high-end, digital camera backs. Throughout the 1990s Scitex has become an industry leader in professional digital photography, and thousands of its products are in use today.

These acquisitions enabled Scitex to cover the full digital process from image capturing to digital printing. During this time, the company continued to develop and offer innovative products and solutions for digital preprint (prepress). Thereby supporting the company's vision which was stated as follows:

Our vision is to build on our leadership position in the prepress market and provide digital tools for presenting data in all emerging new media formats: digital imagery, printing, and video. 


\section{THE PRINTING INDUSTRY IN THE NINETIES}

The printing industry is responsible for the manufacture of printed goods. It is commonly referred to as "graphic communications" or "the graphic arts industry". It is also just as commonly known as the "printing industry". Many use these terms interchangeably. Graphic communications is defined as the processes and industries that create, develop, produce and disseminate products, utilizing or incorporating words, pictorial images to convey information, ideas and feelings.

The first step is the Prepress. This includes all the steps necessary to prepare the print job for press. Procedures here include creating, designing and preparing text and images for output. Press, of course, is the where the actual printing or reproduction takes place. Postpress is the final step. This is where the printed matter is converted into a finished product by binding, finishing, and distribution. Scitex focused heavily on the first and second steps of the printing industry.

During the middle of the 1990s, the evolution of the graphic arts market place accelerated. Industry consolidation continued and significant changes in product pricing and volume took place as did the accompanying need for fundamental changes in distribution strategy. New technologies reduced demand of existing customers and increasing competition made the years 1995 and 1996 very difficult for Scitex. Things did not get easier for Scitex in the next few years.

In 1994 the size of the printing industry was more or less $1 \%$ of the national economy. There was a variation between countries - from $0.5 \%$ of the GDP in the U.K. to $2.6 \%$ in Sweden, but the U.S. with $1 \%$ of the GDP (= $\$ 70,655$ million) set the norm. As economies and GDP increased or decreased over the years, the printing industries followed suit. This was confirmed both by the Business Intelligence (BI) activities of Scitex, the annual reports of the Heidelberger group, and various other interested BI groups. Indeed, the Heidelberger group devotes a chapter of every annual report to 'Economic trends' or 'Business environment' and specifies the changes in GDP in various parts of the world, as a base of comparison to its annual performance.

Dr. Ronnie H. Davis, chief economist for Printing Industries of America, Inc. stated in 1996 that:

...The bottom line has seen an impressive recovery in profitability. Profits as a percent of sales (before taxes) hit a low point of 1.98 in 1991, reflecting the recession. Profits rebounded to 2.34 percent in 1992, 2.54 percent in 1993 and 3.3 percent in 1994. Profits dropped slightly to 3 percent in 1995 as a result of slower economic growth and rising paper prices. Still, 1995 industry profit rates were the second highest since 1988 and profits are expected to remain healthy over the next year.

\section{MAJOR PLAYERS IN THE INTERNATIONAL PRINTING INDUSTRY}

Major competitors included giants like Heidelberger Druckmaschinen AG (www.heidelberg.com) which was a major player whether you looked at prepress (through its acquisition of Linotype), or the printing segment, where it set its focus. They themselves described their company as “...The world's largest press manufacturer and provider of complete print solutions for printers worldwide."

Few Would Argue. Key Financial Data For Heidelberger Look Follows

\begin{tabular}{|l|c|c|c|c|c|c|}
\hline Figures in Euro millions, Exc. EPS & $\mathbf{9 4 - 9 5}$ & $\mathbf{9 5 - 9 6}$ & $\mathbf{9 6 - 9 7}$ & $\mathbf{9 7 - 9 8}$ & $\mathbf{9 8 - 9 9}$ & $\mathbf{9 9 - 0 0}$ \\
\hline Net sales & 1,906 & 2,191 & 2,586 & 3,514 & 3,948 & 4,600 \\
\hline Net profit & 110 & 137 & 180 & 240 & 256 & 251 \\
\hline EPS & 2.2 & 2.74 & 3.6 & 2.8 & 2.98 & 2.91 \\
\hline
\end{tabular}


Another major player was Agfa (www.agfa.com). In their own words:

...Most people know us as a manufacturer of consumer products such as photographic films. But Agfa is much more; we supply all kinds of high-end 'imaging' solutions. Hardware, software, and digital imaging products account for an increasing part of our turnover. This is true for our consumer products, but also in the other divisions such as Prepress Systems, HealthCare and Industrial Imaging.

Key Financial Data For Look As Agfa Follows

\begin{tabular}{|l|c|c|}
\hline Figures in Dollar millions & $\mathbf{1 9 9 9}$ & $\mathbf{2 0 0 0}$ \\
\hline Net sales & 4,731 & 5,260 \\
\hline Margin & $7.7 \%$ & $10 \%$ \\
\hline
\end{tabular}

A third competitor to be weary of was Fuji (www.fujifilm.co.il). The company is based in Japan, and internationally controls a vast network of manufacturing plants on all continents, with subsidiaries and exclusive agents in almost every country on earth. Fuji is “... involved in the development, manufacture and marketing of I\&I (imaging and information) technology and products including, amongst others, optical and magnetic computer media, video, etc".

Key Financial Data For Fuji Look As Follows
\begin{tabular}{|l|c|c|c|c|c|c|}
\hline & $\mathbf{1 9 9 5}$ & $\mathbf{1 9 9 6}$ & $\mathbf{1 9 9 7}$ & $\mathbf{1 9 9 8}$ & $\mathbf{1 9 9 9}$ & $\mathbf{2 0 0 0}$ \\
\hline Sales & 5,403 & 10,119 & $10,097.7$ & $10,439.9$ & $11,822.7$ & 13,658 \\
\hline Net income & 315.1 & 679.7 & 688.3 & 672.9 & 591.2 & 827 \\
\hline EPS & 0.59 & 1.23 & 1.34 & 1.31 & 1.15 & 1.61 \\
\hline
\end{tabular}

Although it would be possible to mention many other competitors (like NUR of Israel, KBA of Germany, and many others), Fuji, Heidelberger and Agfa were among the largest that Scitex was up against.

The analysts conclusion of 1998 was that the printing industry was shifting towards digital technologies, what was termed "...its biggest revolution since the invention of the printing press." "3 This caused Scitex to shift from a manufacturing based outlook to a value-added concept, from a uniform product to one that is personalized, and from local to distributed printing. No local manufacturer could compete. In fact, the competition between the giants was ever increasing, and moved from specialized equipment to end-to-end solutions, which was based on a combination of products and services.

These changes shaped the industry in a way that there were no real alternative products or options for a buyer, and the risk of market penetration by a new player was limited. The market was played by the big boys only, and long standing experience was a key issue both for the high-end customers (such as newspapers, major publishing establishments, etc.) and the mid-range (local newspapers, printing service vendors). Scitex had a wide variety of customers in these two segments; indeed, its three largest customers composed less than $20 \%$ of its annual sales (and therefore Scitex was not required to report them in its SEC filings). Only at the low-end of the market could others compete, as companies such as Scitex were not interested in that segment. Focusing on the preprint industry (digital preprint, since the analog had all but become extinct), Scitex had a 25\% market share of a $\$ 2$ billion market.

The buyers, once decided on a supplier, only seldom changed their whole apparatus; they tended to buy new products and services that built on and completed their existing machinery. Therefore, the buyers held quite a bit of bargaining power at the set-off, but tended to loose a lot of it once settled in.

\footnotetext{
${ }^{3}$ Scitex Annual Report, 1998
} 
Since each of the players was an international one, all had to deal with various kinds of government regulations, tax laws, etc., as that is true for any international conglomerate, and the printing industry presented no special difficulties, as opposed to security related industries, for example.

The major suppliers of Scitex in the 1990s included Intel and IBM, although Scitex made sure not to be solely dependent on any one supplier, in any given field.

\section{AN ERA OF CHANGE}

During the period 1992 - 1994 Scitex's financial figures showed a steady decline in profits. In order to remedy its declining success, Scitex was looking for new ways to grow and decided to do so through a series of mergers and acquisitions, simultaneously buying up companies and developing new technologies. The ruling attitude was "Scitex can do everything". Everything was relevant, as long as "it had color, graphics, was new and exciting". This included Macintosh Desktop graphics software, AOL, multimedia, video teleconferencing, web browsers, printing technologies, and more.

As figures were declining, Arieh Rosenfeld, Scitex's president for the last five years, was replaced by Yoav Chelouche, the former VP of Marketing and Business Development. The appointment of Yoav Chelouche was received well within the company. Chelouche was a Scitex man, not an outsider; he knew the company and people knew him. For the Israeli based employees it was also a welcome addition that he was located in Israel, whereas the former CEO managed the company from his office in Brussels (after he started 'Scitex Europe' there in his previous role).

Yoav Chelouche redefined what Scitex was all about:

...With a strong leadership in the graphic arts, digital video and digital printing markets, Scitex is uniquely positioned for providing efficient tools for delivering visual messages in all types of media, and committed to maintaining a dominant role in the global market for visual information communication.

The newly appointed CEO decided on restructuring the company at the end of 1994. The reorganization program included mass layoffs and organizational changes. Scitex ceased to be one business unit and finalized a process (which had started beforehand) of turning into a company comprised of three strategic business units (SBUs): Graphic Arts, Scitex Digital Printing (SDP), and Scitex Digital Video (SDV). Each SBU was responsible for different technologies and markets and each was responsible for its profit and loss (P\&L). This was a completely new way of managing a firm in Israel; this decentralized management approach was developed abroad and Scitex was among the first companies in Israel to embrace it.

The restructuring process included a re-focus on the core business of Scitex, and the transfer of significant power from the corporate to the SBUs. The motto was "Back to business" and "All the way to print". Each SBU decided on how to advance itself, in which direction it should go, where its markets were positioned, what joint ventures it should join, and what alliances it should forge. Although the SBUs were not totally independent, Yoav Chelouche allowed the CEOs of the SBUs a degree of latitude they never had before.

\section{THREE SBU'S}

'Graphic Arts' was the largest SBU and was focused on providing solutions for printed visuals, at all stages of printing. Its mission was: "Providing graphics arts solutions from image creation and origination all the way to short-run digital printing".

Its customers had a decidedly graphic orientation and came from the preprinting industry, the printing industry, the photography industry and the high-quality visuals publishing. Worldwide this SBU included 2,600 employees in 1995. The financial figures of 1995 showed that while sales were increasing $(\$ 600 \mathrm{M})$, profits were negative, forcing the SBU to adapt a cost slashing program with the target of reducing expenditures by $\$ 30 \mathrm{M}$, 
increasing the materials turn over and reducing credit days given to customers. The program was successful, and the Graphic Arts division became profitable once again.

Financial Highlights Of $1995^{4}$

(\$ In Thousands, Except Per Share Data)

\begin{tabular}{|l|c|c|}
\hline Year ended December 31 & $\mathbf{1 9 9 5}$ & $\mathbf{1 9 9 4}$ \\
\hline Total Revenues & 728,900 & 704,138 \\
\hline Gross Profit & 319,578 & 367,998 \\
\hline R\&D expenditure (net) & 74,961 & 73,258 \\
\hline Operating income (loss) & $(54,306)$ & 71,081 \\
\hline Net Income (loss) & $(34,511)$ & 63,750 \\
\hline Earnings (loss) per share & $(0.81)$ & 1.49 \\
\hline Shareholders' equity & 700,981 & 749,735 \\
\hline
\end{tabular}

The second SBU, 'Scitex Digital Printing' (SDP) was located in Dayton, Ohio, USA. It specialized in printers and peripheral equipment designed for massive printing jobs, based on digital technologies. Its mission was: "Providing very high speed variable data inkjet printing systems for personalized long runs". SDP employed around 500 employees in 1995. Its customers were newspapers, packaging manufacturers, label and form printing shops. In 1995 its sales increased by $20 \%$ (compared to 1994) and it, too, was a successful SBU.

The third SBU, 'Scitex Digital Video' (SDV) was comprised of two companies that Scitex had acquired in 1994-95: ImMIX and Abekas. Both were California based companies, whose products complemented each other. The SBU offered digital tools for Video graphics manipulation and editing. SDV employed 270 employees in 1995. Its mission was: "Providing tools for digital video production, including editing, manipulation, and special effects". Its customers were professionals in the video industry.

\section{REVENUE DIVISION BETWEEN SBU'S, 1996}

The restructuring process was finished in 1996. The results were varied: Graphic Arts had its problems, but managed to overcome them and show significant profits; Scitex Digital Printing was a success; however, Scitex Digital Video was not.

A worldwide graphic arts conference on visual information communication (Scitex World) was held in 1996. A highlight of the conference was demonstration of the world's first fully integrated, digital front end for output devices, with full imposition and all preprint tools (Brisque Impose).

\section{Revenue Breakdown, By Division, $1996^{5}$}

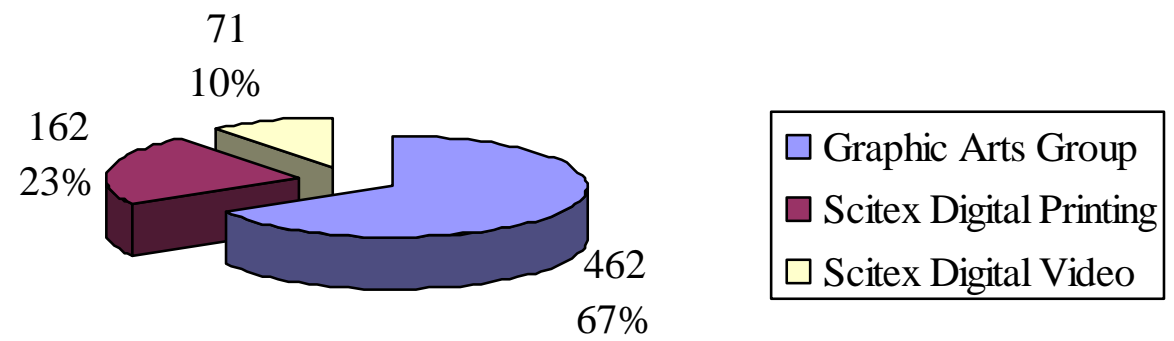

${ }^{4}$ Scitex Annual Report, 1995
${ }^{5}$ Scitex Annual Report, 1996 


\section{EXTRACTS FROM “A LETTER TO OUR SHAREHOLDERS”, SCITEX ANNUAL REPORT, 1996}

Dear Shareholder, the year 1996 was an extremely difficult one for us, maybe the worst in Scitex's history. It was the year in which Scitex made and implemented many difficult decisions necessitated by the accelerating consolidation of the graphic arts industry. We believe we have taken the correct steps to position ourselves for the future. These steps, as well as general industry conditions, necessitated 110 million in write-offs and provisions which are included in the net loss of 178 million for the year. Revenues in 1996 fell 5\% to $\$ 695$ million...

The problems we faced in 1996 were not exclusively external or industry oriented. When it became clear that demand for some of our graphic Arts products would not return to previous levels, and that it would be necessary to cut expense levels, we tightened our credit and shipment policies and initiated a number of programs to clear inventories in existing distribution channels.

As the level of competition intensified, we made efforts to increase the standards of service we offer to our customers, and to improve the reliability of our products... We also implemented a restructuring plan for the Graphic Arts unit. The plan consisted of the following key elements:

A $17 \%$ reduction in staffing levels, and a $\$ 40$ million per annum reduction of operating costs and manufacturing overheads... Closing facilities and offices across the US and Europe... focusing on the five major product families that offer the most promising opportunities in this area of our business... Although we are obviously disappointed by the financial results of 1996, we believe we have taken correct, albeit painful steps to position Scitex for the road ahead.

Dov Tadmor, Chairman of the Board

Yoav Z. Chelouche, President and CEO

The year 1997 was especially significant in that Scitex launched many innovative and advanced products. At the Imprinta 97 tradeshow in Germany, Scitex unveiled the world's first, fully-automatic, color, all-digital offset press that dramatically reduces make-ready (74 Karat). At the same tradeshow, Scitex demonstrated other firsts in the industry: an affordable, integrated, dry film image setter (Dolev 2dry); a compact, fully-automatic, computer-to-plate system with continuously-variable resolution (Lotem $800 \mathrm{~V}$ ); and a tabletop color scanner with high resolution over the entire format (EverSmart).

In marked contrast to the other two SBUs, the SDV division failed to overcome its problems and to establish stable, profitable business results.

In 1997 Scitex initiated and successfully implemented a recovery plan for the Graphic Arts group. As a result, both the Graphic Arts division and the Digital Printing division were feeling that they were "conquering the world" (there was even serious consideration of buying the prepress parts of Agfa and leaving them only with the consumables, but somehow that deal never went forward), while the SDV division dragged the financial results of Scitex down to a "modest profit, after two years of losses". These results were infuriating both to the successful divisions and to senior management.

\section{FINANCIAL RESULTS OF THE RECOVERY PLAN, 1998}

Towards the end of the millennium, Scitex had greatly enriched and expanded the product line of its core business - digital preprint. At the same time, Scitex has expanded the product line of its growth business - digital printing. However, management of 'Scitex Digital Video' had not only been unable to turn the SBU around, its performance was so disastrous that it was sold at an extremely low price in 1998. "To concentrate on our core business, we exited the digital video business, during 1998... The sale of the division resulted in a loss". 6

\footnotetext{
${ }^{6}$ Letter to our Shareholders, Scitex Annual Report, 1998
} 

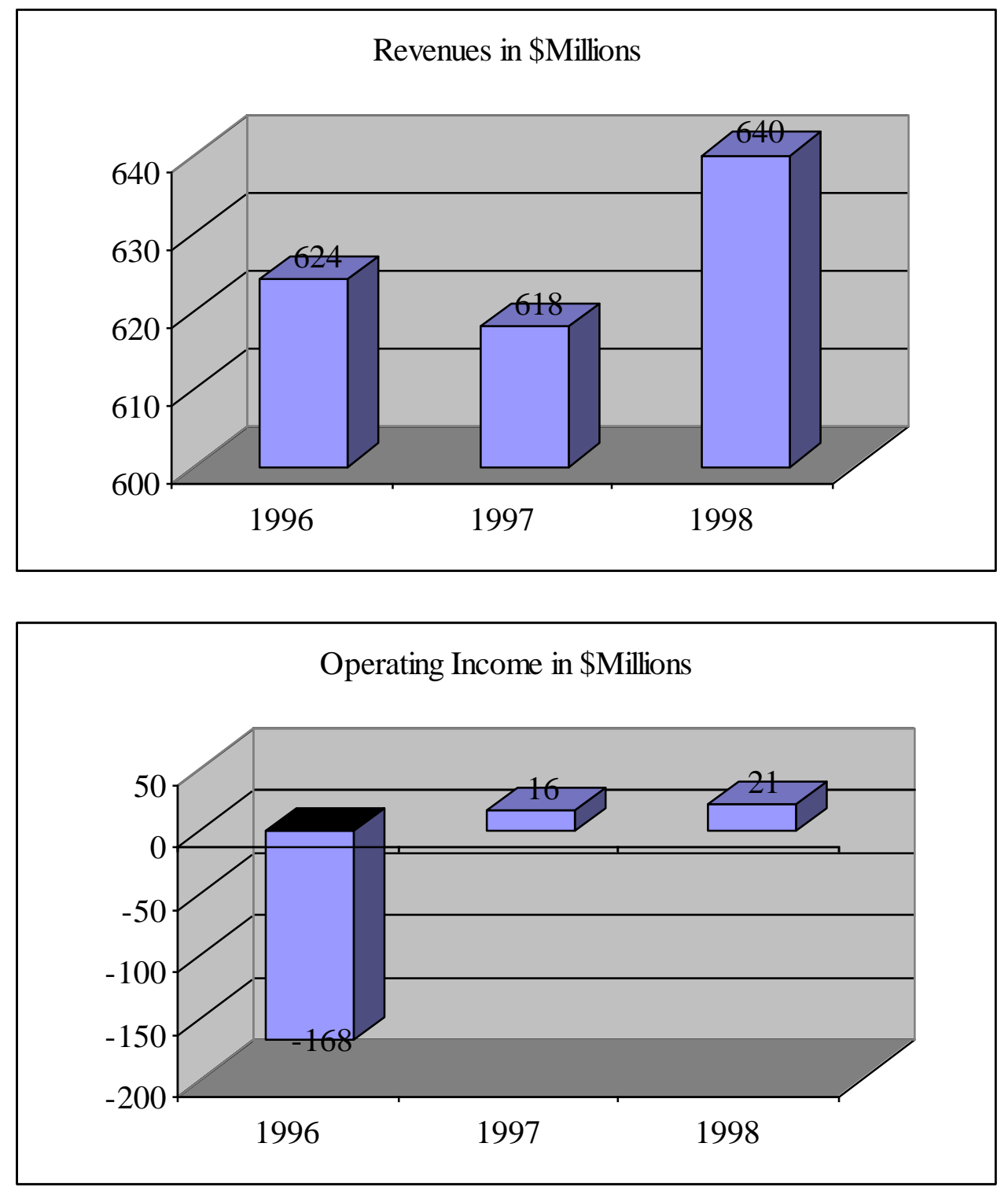

In 1998 Scitex also purchased "Idanit" and "Matan" and created a new SBU, which included these acquisitions; the SBU was named 'Scitex Wide-Format Printing' and was located in Herzliya, Israel. It specialized in wide and super-wide format printing machines, whose products are placed on billboards, wide banners, posters, and so on. The customers that used such products were advertising agencies of all kinds.

Creation of this new SBU placed Scitex at the forefront of wide and super-wide format inkjet printing of billboards, banners, displays, and many other innovative applications of these color printers. The SBU underlined the preeminence of Scitex in inkjet printing for industry.

The SBU was an immediate success, as was pointed out in the annual letter to the shareholders in 1998:

...By the end of the year, the new wide-format printing division had more than 100 systems installed, each a source ongoing of revenue from the sale of consumables. 
In 1999, its revenues further grew to approximately $\$ 43$ million, which represented an increase of over 50\% in revenues compared to 1998 .

\section{THE FINAL COUNTDOWN}

By 1999 things were looking bright. The first quarter's results showed a bottom line profit for the whole company, and expectations for next quarter's results were even better. The Israeli high tech industry was at its peak and established new rules of business behavior, goals, and vision. In that year the company's vision changed to:

... building a network of leading, innovative companies focused on combining digital imaging technologies with the power of the Internet, to create a world of visually rich business communications... working to enhance the value of our network companies, through the exchange of intellectual property assets, by leveraging complementary technical and operations skills, and by drawing on the broad experience of our management teams. ${ }^{7}$

During that period, Scitex entered the new Internet market, since the “... internet offers significant opportunities for innovation in Internet imaging, to meet the needs to efficiently handle large image and data files in a bandwidth constrained environment. Scitex provides Internet technologies and telecommunications services that change the way visual communications are created and distributed".

The company's motto became to "unveil value". High tech companies sought to demonstrate how much they were actually worth, how attractive they were compared to other companies. This left Scitex at a disadvantage. Until 1999, senior management had been occupied with the restructuring program, trying to turn all Scitex's SBUs in profitable businesses. Moreover, coming from traditional industries, Scitex did a lot to develop and deploy new technologies, but it lacked a certain amount of "sexiness", or sudden and major growth. The board came under pressure to adapt to what was known as the "new economy" and to plan its future according to the new rules.

Naturally, the company and its SBUs had never stopped creating and enhancing their value. The SBUs especially, had worked on new products, alliances, joint ventures, etc. The drive to brand themselves as independent entities, which are responsible for their own success, was high. There was even some feeling of envy towards the SBUs of another Israeli high tech company, ECI, where the branding went so far as having the SBUs' names and logos on the company cars, instead of the corporate "ECI" name and logo. The Scitex SBUs wanted that kind of independence, too.

In April 1999, with the appointment of a new Chairman of the Board, Rimon Ben-Shaul, everything came together. The whole company was making money again, Israeli high tech was at its high and demanding new rules, and "new blood" had just entered top management. The board started to consider strategic options.

One option for further exposing Scitex's value was to allow this drive to continue, indeed to take it one step further, by issuing stock for each SBU, independently of Scitex shares, on the various stock markets. In the eyes of many of the SBU managers that idea seemed like a logical conclusion to the existing developments. The strategic logic behind this was to let the SBUs continue doing what they already were doing in a successful way, while rewarding them for all the hard work they had done. The strategic shift would be to further decrease the importance and the control of the corporate function over the SBUs, and to let the SBUs continue their growth almost completely independently.

Another option would be to increase value by doing the exact opposite: uniting functions and operations where ever possible, cutting costs by unifying services, raw materials, warehouses, etc. That way, Scitex would have a lean as possible organization leading to lower expenditure, and therefore to increased value. However, it seemed that this option would not satisfy the board and it would not satisfy the management of the SBUs; in short - it was a theoretical option only.

\footnotetext{
${ }^{7}$ Scitex Annual Report, 1999, Moving Forward
} 
A third option that was considered was merging all or parts of Scitex with another company, buying another firm completely (in order to increase market share, number of markets, technologies Scitex would reach, and so on), or to be bought by a different company, one of the printing giants of the world. This last option reminded people of bumper stickers that could be seen on some start-up company cars: "Buy me, Maxwell" (Maxwell was an extremely rich, Jewish businessman, who had very strong business ties in Israel and even served as Chairman of the Board of Scitex after Efi Arazi, the founder, left).

Senior management and had had its eye on exiting the prepress industry since the early nineties, but could not go ahead with this strategic move until the largest SBU was stable and profitable again. The reason was that senior management foresaw the major changes this industry would undergo, and concluded that it was only a matter of time until this source of income would turn into a liability. The idea to sell out or merge with another prepress company was advocated by senior management to the Board. Not everyone (especially in the Graphic Arts Division) approved of this move.

All the options were valid, although clearly the third option was the one that would create a most dramatic change. Opinions differed whether Scitex should merge, be bought out (allowing to bring in cash rewards for all the hard work) or wait just one additional quarter (just one!) in order to accumulate enough cash to buy another company. Such a move would put Scitex in the lead in additional markets and/or the prepress-press market, and would mean that senior management would have to start a whole new ball game.

Creo Products Inc., for example, was thought to be a rising star in the prepress-press industry, with products that complemented or competed with those of Scitex. A merger would provide the combined firm with a major market share of the entire pre-press and digital press market. A merger with Creo would allow Scitex to create a major boost to its value, or so it seemed, and the main question was whether to merge now, to sell the SBU outright, or wait another quarter and buy Creo (something not everyone in management agreed was realistic).

Any one, or combination of the above options, was possible; the Board and the stockholders wanted to go ahead as soon as possible. With the appointment of Rimon Ben-Shaul as Chairman of the Board, the final decision was about to be reached; the countdown was over and the decision was at hand.

Scitex had reached the summit. It had overcome all its difficulties, had divested itself of the parts that needed to be shed, had reestablished itself as a major player in the pre-press-press industry and the future was looking bright. Scitex had reached an annual sales figure of $\$ 700$ million and the possibility of reaching a round $\$ 1$ billion looked realistic to senior management. Q4 of 1999 was expected to include revenues of over \$190 million and operating income of at least $\$ 15$ million. Now was the time to decide where to go. The Board wanted to know how Scitex would make the next big leap, how it would "unveil its value" even further. The Board met on December 1999. This was to be the meeting where the future was decided upon.

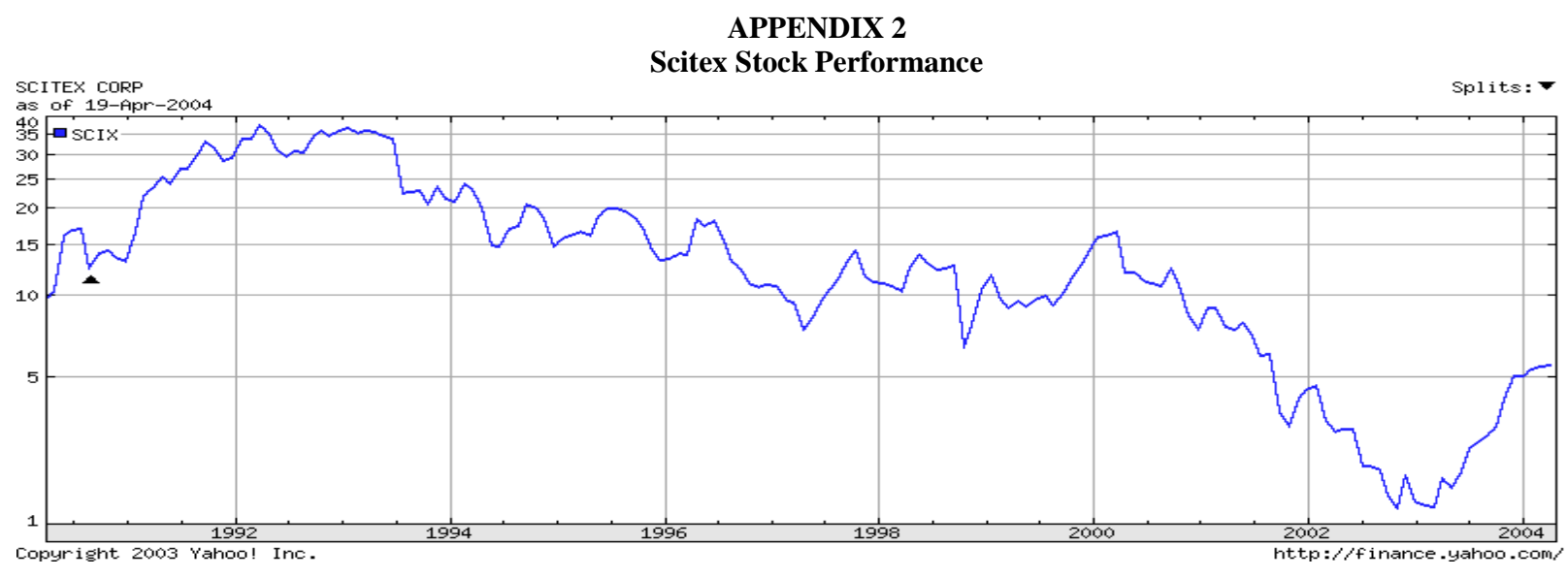


APPENDIX 1

Financial Data 1995-1999

U. S. Dollars In Thousands Except Per Share Data, For Year Ended December 31

Revenues:

Sales

Service

Supplies

Total Revenue

Cost Of Revenues:

Cost Of Sale

Cost Of Service

Cost Of Supplies

Total Cost Of Revenues

Gross Profit

Expenses:

Research And Development Expend. Net

Accrued In-Process R\&D

Sales and Marketing

General And Administrative

Amoritization Of Goodwill And Intangilbles

Restructuring Costs

Operating Income

Other:

Financial Income, net

Other Income Net

Income Before Taxes

Taxes On Income

Share in Income Of equity Investments

Income From Continuing Operations

Discontinued Operations:

Income From Discontinued.. Operations

Gain / Loss on Disposal

Net From Discontinued Operations

Net Income

Earnings Per Share:

Continuing Operations

Discontinued Operations

Total

Weighted Average Number Of Shares:

Basic

Diluted $\underline{1999}$

475,370

146,814

68,266

690,450

242,442

118,365

35,908

396,715

293,735

65,522

101,449

65,799

11,393

49,572

3,432

1,221

54,225

9,180

$-21,481$

23,564

6,965

6,965

30,514

0.55

0.16

0.71

42,661

42,983

\section{$\underline{1998}$}

441,399

137,823

61,089

640,311

227,564

108,274

33,198

369,036

271,275

66,498

44,264

100,855

74,142

9,285

$-23,769$

4,971

1,634

$-17,164$

2,231

$-14,897$

$-34,292$

$-13,831$

$-62,704$

$-76,535$

$-110,827$

$-0.80$

$-1.78$

$-2.58$

42,929

42,929 $\underline{1997}$

426591

134183

56885

617659

234220

110771

28535

373526

244133

57,610

91,327

72,584

6,215

16,397

5,941

$-10,002$

21,338

1,500

$-2,742$

17,096

$-16,514$

$-16,514$

582

0.40

$-0.39$

0.01

42,809

43,154 $\underline{1996}$

$\underline{1995}$

533084

115824

36132

685040

51350

624105

253819

123691

16548

394058

290982

415996

208109

61,273

67390

129,619

116,596

9,347

22,000

$-53,970$

56,100

$-167,983$

9,929

$-2,475$

$-46,516$

$-13,464$

$-1,123$

$-34,175$

$-336$

$-336$

$-34,511$

$-178$

$-3.77$

$-0.39$

$-0.80$

$-0.01$

$-0.81$ 